\title{
NOTES ON LEONARDO BOFF AND THE FILIOQUE
}

\author{
Ernst M Conradie \\ University of the Western Cape
}

\begin{abstract}
There are a number of recent theological movements that tend to emphasise the freedom of God's Spirit to "blow wherever it wants to". This contribution focuses on the work of Leonardo Boff as a representative of two such movements, i.e. liberation theology, and ecological theology. In particular, it investigates Boff's understanding of the work of God's spirit as articulated in his recent book "Cry of the Earth, cry of the poor" (1996).
\end{abstract}

\section{Introduction}

There are a number of recent theological movements that tend to emphasise the freedom of God's Spirit to "blow wherever it wants to". These movements include, to a lesser or a greater extent, a variety of indigenous theologies ("God's Spirit was here in South Africa before Christ came"), Pentecostal theologies, including African Pentecostalism (new encounters with God's Spirit and the free gifts of the Spirit), liberation theologies (the political work of the Spirit outside the church), feminist theologies (the feminine face of the Spirit as a counter to a male Christ), religious pluralism (the universality of the Spirit is preferred to the exclusiveness of Christ) and perhaps also ecological theologies ${ }^{1}$ (the cosmic scope of the Spirit's presence). These approaches raise numerous theological questions regarding the relationship between the Spirit and Jesus Christ.

This contribution will focus on the work of Leonardo Boff as a representative not only of liberation theology, but more recently also of ecological theology. ${ }^{2}$ In particular, I will investigate Boff's understanding of the work of God's spirit as articulated in his recent book Cry of the Earth, cry of the poor (1996).

\section{Boff's approach to ecological theology}

Boff's work is in many ways representative of an approach to ecological theology that has become quite common. The following features of this approach may be identified:

a) In Boff's work there remains a strong emphasis on issues of justice. The link between economic injustices and ecological deterioration is the topic of many recent ecumenical contributions to ecological theology. This link is captured in the notion of "eco-justice" where the "eco" (based on the Greek oikos) refers to both economy and ecological injustices. The struggle for eco-justice seeks to challenge the abuse of power that results

1. Ecological theology may be understood, together with liberation theology, black theology, feminist theology, womanist theology and various indigenous theologies, as a next wave of contextual theology. Ecological theology, in particular, is obviously elicited by the widespread concern over environmental destruction. It draws on the Christian tradition for wisdom and resources to respond to such environmental destruction. At the same time, it also calls for a multi-levelled transformation of the Christian tradition in the light of the challenges posed by environmental destruction.

2. In several recent contributions Boff has explored the relationship between liberation theology and ecological theology. See especially Boff (1995, 1996, 1997), Boff \& Elizondo (1996). Boff also draws widely on insights emerging from ecofeminism and from indigenous theology. See also the contributions by Gebara (1995, 1996, 1999) drawing on liberation theology, indigenous theology and ecofeminist thinking. 
in the situation that poor people have to suffer the effects of environmental damage caused by the greed of others. ${ }^{3}$ Dieter Hessel defines "eco-justice in the following way:

Eco-justice provides a dynamic framework for thought and action that fosters ecological integrity and the struggle for social and economic justice. It emerges through constructive human responses that serve environmental health and social equity together - for the sake of human well-being with otherkind. ${ }^{4}$

This link between ecological deterioration and economic injustice is neatly articulated in the title of Boff's work Cry of the Earth, cry of the poor. The logic that exploits the oppressed classes and subjects peoples to the interests of a few rich and powerful countries is the same as the logic that devastates the Earth and plunders its wealth. ${ }^{5}$ In this context, Boff offers a sharp critique of the economic models of sustained growth and of sustainable development. As a citizen of Brazil, he is particularly concerned with the destruction of the Amazon rainforests by macro-economic projects that are insensitive to the ecological balance of this bioregion. This is leading not only to a loss of biodiversity but also to injustices towards indigenous peoples (86-114). In fact, the poor are the most threatened beings in creation (110f). To emphasise the link between people and the environment, Boff prefers to use the term "social ecology" instead of other forms of ecological awareness where the emphasis is on the natural environment only (105). ${ }^{6}$

b) In Boff's work there is an overwhelming emphasis on a retrieval of concepts such as "ecological wholeness", "interconnectedness", a "holistic" approach, the "community of life" 7 and a sense of the dignity and sacredness of the Earth. These themes have been reiterated in numerous contributions to ecological theology, most notably in indigenous theologies, ${ }^{8}$ eco-feminist theologies, the creation spirituality of Matthew Fox, some exponents of process theology and numerous others. This correlates with what Rosemary Ruether has called a sacramental approach to ecological theology. ${ }^{9}$ Such a sacramental approach draws on the Bible and on patristic and medieval mysticism to speak to the heart, to inspire a vision of the sacred and to express an ecstatic experience of communion within the earth community. It is distinct from a covenantal approach that draws inspiration from the Bible and the covenantal tradition to emphasise a commitment for right relationships (e.g. with reference to a theology of stewardship ${ }^{10}$ ) within the earth community.

Boff regards the disruption of connectedness as the ultimate root of the ecological crisis. He speaks of a new paradigm that is coming to birth in which connectedness and the sense of a planetary community will form the basis for a universal religion. It will seek convergences through restoring the sacredness of all things, reclaiming the dignity of the Earth, rediscovering the mission of human beings to celebrate communion and

3. Information brochure of the Environmental Justice Networking Forum in South Africa.

4. Hessel (1996:18).

5. See Boff (1997:xi). Subsequent references to this work will be indicated in the text in brackets and by page numbers only.

6. See also Boff $(1994,1995)$.

7. See also Sindima (1989).

8. Boff (1997:122f) identifies five aspects of the ecological wisdom of original peoples: 1) ancestral wisdom, 2) the sense of the mystique of nature, 3) an understanding of work, not merely as production, but as the collaboration that human beings give to Mother Earth in handling human needs, 4) the emphasis on celebration and dance, 5) the emphasis on the experience of God.

9. See Ruether (2000).

10. See Conradie (1999) for an assessment of a theology based on the metaphor of stewardship. 
life, and encountering the mystery of God (xii). It will draw not only on instrumental reason (logos) but also on affectivity and sensitivity (pathos), passion (eros) and nature's inner voice (daimon) (12). It is characterised by wholeness, interdependence, complexity, complementarity, reciprocity, creativity, the common good and a shared destiny (31-34).

c) Many ecological theologies draw inspiration from contemporary science, most notably from the "story of the universe" as reconstructed by astrophysicists, geology, evolutionary biology and other sciences. Many find an ecological moral to this story. On the one hand, the story of the universe illustrates the insignificance of the human species in space and time amidst the vast dimensions of the cosmos (119-120). This may help to counter the dominant culture of anthropocentrism (70-71) and to rediscover our place in the cosmos and in solidarity with the rest of the earth community (121). On the other hand, this story illustrates the significance, in terms of a high degree of complexity, of the emergence of the human species. This may help to emphasise human responsibility towards the earth community.

Boff offers his own account of the history of the cosmos and of the emergence of a living planet (Gaia) (15f, 43f, 119f). He concludes from this story that the ecocide for which the human species is responsible renders it to be the Satan of the earth $(19,69 f)$. He draws widely on insights from contemporary science, including astrophysics, quantum theory, molecular biology, thermodynamics, chaos theory, etc. Recent developments in these fields illustrate for Boff the thrust of the new paradigm in which there is room for a non-linear logic characterised by complexity, self-organisation (autopoesis), openness, novelty and mystery (11-33).

d) In Christian theology, this use of contemporary science has to be understood in terms of the need for a reintegration of the themes of creation, redemption and consummation. An adequate creation theology cannot be reduced to soteriology. Many ecological theologians seem to regard the dialogue with contemporary science as crucial to secure a "realistic" focus in creation theology. A theology of creation has to clarify its truth claims in relation to the origins of this earth if it is not to be reduced to a mere language game situated in a particular culture.

Moreover, an ecological doctrine of creation has to draw on a doctrine of God that can do justice to both the transcendence of a Creator God and the presence of God in the history of the cosmos. For many, the immanence of God is particularly important to avoid the alienation between God and the world resulting from a deist notion of God. ${ }^{11}$ The presence of God in the created order also seems to emphasise the sacredness of the earth as God's dwelling place. Many ecological theologians are attracted to panentheism in order to highlight both God's immanence and transcendence. Ecofeminist theologians often speak of the world as God's body. ${ }^{12}$ The notion of God's primordial self-withdrawal in order to make room for the emergence of creation within God (zimsum) is often used to develop a doctrine of creation from such a panentheist point of departure. ${ }^{13}$

Boff supports such a panentheist position explicitly. He argues that God is present in the cosmos and that the cosmos is present in God. He criticises pantheism for failing to

11. See, for example, Moltmann $(1985,1989)$ for such an emphasis on the immanence of God in creation. Moltmann says: "If the creative God himself dwells in his creation, then he is making it his own home, 'on earth as it is in heaven'. All created beings then find in nearness to him the inexhaustible wellspring of their life, and for their part find home and rest in God" (Moltmann 1985:5).

12. See Jantzen (1984), McFague (1990, 1993), Rae (1994:71f).

13. On the notion of a primordial zimsum, see also Haught (1993), Moltmann (1985), Müller-Fahrenholz (1996). 
make a distinction between God and the world. This lack of difference may easily lead to indifference. All is not God. However, God and the world cannot be separated either. They are open to one another and intertwined with one another (153). Therefore, "In embracing the world, we shall be embracing God" (xii). Boff here refers to Teilhard's notion of transparency to explain both God's transcendence and God's immanence. Transparency is the presence of transcendence within immanence. When this happens reality becomes transparent. "The great mystery of Christianity is not exactly the appearance, but the transparence of God in the universe."14

\section{Boff's notion of God's Spirit}

Boff develops his theological position from a point of departure in Teilhard's well-known evolutionary schema. Teilhard identified a tendency toward increasing complexity in evolutionary history in terms of the four phases of cosmogenesis (the coming into being of the cosmos), biogenesis (the emergence of life), noogenesis ${ }^{15}$ (the emergence of consciousness) and Christogenesis (the transfiguration of the cosmos according to the image of the incarnate Christ). Boff builds on this form of natural theology and develops it into a trinitarian vision in which the cosmos participates in the interplay of perichoretic relationships in the life of the trinity. ${ }^{16}$ Let us trace the development of his argument:

a) Boff notes that God's reality need not be brought in from the outside on the basis of a revealed treasury of some religious tradition. God's reality is a manifestation of the religious dimension of Earth itself. This is evident from experiences of sacredness, enchantment, "noble silence: (Eckhardt) and, above all, in the sense of mystery that is common to all cultures. This sense of mystery, which Boff refers to as the "theosphere", allows for the development of a natural theology: "God is the name we give to this mystery enveloping us on all sides and flowing over us in all realms." (140). Boff emphasises the discovery of unfathomable mystery: "Mystery is the dimension of depth to be found in every person, in every creature, and in reality as a whole; it has a necessarily unfathomable, that is, inexplicable aspect." (143). Traces of mystery and the divine presence are evident at the level of quantum mechanics, chaos and throughout the process of cosmogenesis. The divine presence becomes even more evident in the emergence of life on Earth and especially through the emergence of human consciousness.

b) The emergence of a human awareness of the divine presence is possible though the unfolding of what Boff calls "spirit". This unfolding is expressed in the following Eastern poem that Boff is fond of quoting:

The Spirit (God) is sleeping in the rock,

dreams in the flower,

awakens in the animal,

and knows that it is awake in the human being (169).

14. Teilhard as quoted in Boff (1997:154).

15. With Teilhard and Thomas Berry, Boff stresses that human beings are not so much beings on Earth but beings of the earth. We are the most complex expression of the Earth and the cosmos thus far. Noogenesis therefore represents an emergence from the biosphere. We as human beings must rediscover our place in the planetary community alongside other species (106).

16. It should be noted that there is no reference to Teilhard's schema in Boff's earlier work on the trinity (1988). There he does emphasise, following the work of Moltmann (1981), the notion of the trinity as a divine communion and the perichoretic relationships between Father, Son and Spirit. He also discusses the social implications of such a notion of the trinity. However, unlike in his later work (1996) this trinitarian theology is not situated within the context of natural theology or the evolutionary history of the cosmos. 
Spirit is the vital energy that permeates the cosmos. This is particularly recognised in animistic traditions and in indigenous theologies. Everything is filled with this vital energy: "Everything sends us a message; everything speaks or can speak: trees, colors, wind, animals, roads, persons, and household things." (158). Everything has a spirit that allows each to interact with others. This spirit is the dynamism, the energy, breath or wind (ruah) that is present in the lithosphere, the hydrosphere, the atmosphere and particularly in the biosphere. This spirit as cosmic force and vital energy blows wherever it wills and energises the entire cosmogenesis. Boff describes the process of cosmogenesis as one of producing increasing complexity, interiority and connectedness (149-150). The spirit at work in the process of cosmogenesis is epitomised by the human spirit. Here the spirit becomes aware of its own vitality. Indeed, consciousness is the highest and most complex form of life. This allows for a new form of communication, sensitivity and freedom that expresses itself as a force creating unity, communion, communication and meaning (160-161).

God's reality is for Boff far from a mere human construction. Yet, it is only through the human spirit that the spirit that has been active throughout evolutionary history is for the first time recognised as a holy or divine spirit (or Spirit). This Spirit enlivens the whole universe. The Spirit is energy, life, an ever self-actualising process, communicating itself and transcending itself (162). The presence of this Spirit can be detected in our midst through a number of experiences. Boff identifies the following: 1) Ecstasy (an experience of exuberance through an extreme intensification of the presence), 2) Enthusiasm (literally: being inhabited by God), 3) Inspiration (the experience of being possessed by a greater power), 4) Communication (the ability for self-transcendence through the establishment of relationships) and 5) the presence of reasonability and order in the universe (162-163).

c) Boff subsequently develops this form of natural theology towards a trinitarian theology. He notes that the presence of the divine Spirit was identified with the third person of the trinity through the emergence of the Christian tradition. In particular, this was the result of decisions at the Council of Nicea-Constantinople (381 CE) where the divinity and personhood of the Holy Spirit were asserted. Subsequently, the collective mind of the Christian tradition became convinced that the way to name God is trinitarian (164).

In retrospect, the Christian tradition recognised the Holy Spirit as the driving force of the cosmogenic process. The presence of the Holy Spirit permeates the earth. The Holy Spirit became incarnate, it "pitched its tent among us" - in the temple, in the people of Israel, in the prophets, and then descends over Maria (as Boff is keen to add, 168). The presence of the Holy Spirit culminates in the process of Christogenesis. Through the Spirit the divine logos became incarnate in the person of Jesus of Nazareth. In the life, passion, death and resurrection of Jesus there emerged what Teilhard referred to as a Christic consciousness. In the risen one, the evolution of the cosmos becomes a revolution, a refiguration of the world (182). For Christians, these events anticipate the fulfilment of the history of the cosmos that will entail the consummation of all things in Christ (anakephalaiosis) (183). This culminates in a trinitarian vision where the whole cosmos will participate in the life of the trinity. Boff describes this work of the Spirit in the following way:

The Spirit uniting everything inside and outside the Trinity will orchestrate the universal symphony. Ecology will be complete, for all will be in their true oikos in an infinite bond of sympathy, in their maternal and paternal home where the Spirit has ever been dwelling, now fully illuminated and transfigured by the Spirit's utter self-communication (173). 


\section{Boff on the filioque}

Boff affirms the trinitarian vision of the Christian tradition, that is, "the belief in the coexistence, simultaneity, and coeternity of the Father, the Son and the Holy Spirit." (154). However, for Boff, this "trinitarian intuition" is not limited to Christianity. Trinitarian discourse may help to structure ecological insights on the web of relationships and interdependencies, the unity (e.g. the single planet Earth) and the diversity (galaxies, solar systems, biodiversity, and the multiplicity of races, cultures and individuals) that structure the universe. The trinitarian vision is one of perichoretic relationships, immediacy, reciprocities, inclusiveness and communion. Indeed, in the beginning is communion. ${ }^{17}$ The Father, Son and Holy Spirit "relate among themselves so absolutely, they are intertwined so intimately, they love one another so radically, that they become one." (155). For Boff, this implies that, if God is communion and relationship, then the entire universe lives in relationship and all is in communion with all (156). Moreover, the mystery of trinitarian communion becomes a model for any participatory, egalitarian (also trans-sexist) and integrated social organisation. ${ }^{18}$ Boff can therefore state that: "The trinity is our social programme." ${ }^{\prime 19}$ It provides the basis for social and integral liberation. It calls for a society that would be neither capitalist nor collectivist, but that would be one of fellowship, equality of opportunity and generosity. ${ }^{20}$

This portrayal of the trinity in terms of divine communion (the "social analogy") and perpetual divine perichoresis (interpenetration), instead of classic categories of substance and persons, leads Boff to question the staleness of debates on the filioque. ${ }^{21}$ For Boff, the value of the addition of the filioque clause in the West was that it assured the consubstantiality of the three divine persons. It also overcame the suspicion that the Holy Spirit may be a divine creature or merely the presence of God's power in history and not a unique person together with the Father and the Son (165). However, for Boff, the language of procession (the Spirit "proceeds" from the Father) has become restrictive. Instead, the relationships between Father, Son and Spirit are complex, participatory, reciprocal and perichoretic. These relationships cannot be reduced to that of derivation, production or procession. $^{22}$ If the Spirit does "proceed" from the Son as the "Spirit of Christ", it is also true that the incarnation of the Son may be attributed to the work of the Spirit. The Spirit not only proceeds from Christ but also precedes Christ. It is through the Spirit that the child was conceived in Mary (Matt 1:20). It is the Spirit who raised Jesus from among the dead. It is the Spirit that gave rise to the church, the community that bears the legacy of Jesus forward in history (167).

Boff argues that, as a result of the unresolved controversy over the addition of the filioque clause, the Western church has failed to do justice to the vast work of the Holy Spirit in the cosmos, in human history and in the life stories of people in all cultures (165). There has been an "amnesia of the Holy Spirit" in many churches (166). This is evident from the rejection by ecclesial authorities of reform movements, e.g. those led by Joachim of Fiore, Martin Luther and liberation theology. More recently, this has disabled the church to hear the cry of the poor and the cry of the Earth for life and for justice (166).

17. See also Boff (1988) for a more detailed discussion of the trinity.

18. See in more detail Boff (1988:11f, 118f).

19. Boff (1988:16).

20. Boff (1988:151).

21. See also Boff (1988:198-207) for a discussion of the classic debate between East and West on the addition of the filioque clause.

22. See the Kliegenthal Memorandum (1979), Oberdorfer (2001). 
Nevertheless, Boff observes, there has been a very widespread recent interest in a new spirituality that seeks a living encounter with God more than a teaching on God: "They seek not a new religion but a new spirituality, one that places at its center the Spirit who comes from God, permeates the cosmos, bursts into life, emerges very obviously in people's awareness and is celebrated by communities of faith" (166). In this way, Boff wishes to affirm the freedom of the Spirit who blows wherever it wills. The Spirit initiates the renewal of all things, it allows for newness to emerge, it allows differences and complexities to flourish and creates bonds of communion within an irreducible diversity (167-168). The Spirit is the principle that creates differences and communion. ${ }^{23}$

\section{In conversation with Boff}

a) Since I come from a theological tradition that is on the opposite side of the spectrum, it is rather difficult for me to assess Boff's work. There is a typically Catholic emphasis in Boff's work on consonance, integration, harmony and an organic whole. This is particularly evident in his use of natural theology to integrate the scientific reconstruction of the history of the universe with the trinitarian vision of the Christian tradition. By contrast, my own reformed tradition would emphasise the alienation between God and humanity and between humanity and the earth that results from human $\sin .^{24}$ A sensitivity for the impact of $\sin$ in the world and on human knowledge leads to a suspicion against knowledge of God derived purely from natural theology. The language of the reformed tradition therefore allows for stark contrasts between God and the world, for dialectic oppositions, for the unresolved paradox. This language is realistic in recognising that alienation characterises the human condition and that ecological destruction can only be resolved if such alienation can be addressed. It affirms that such alienation can only be overcome by God, and not by innate human capabilities or by an increasing human consciousness of the mystery of the cosmos. Wesley Granberg-Michaelson, the reformed ecumenist, raises similar questions in conversation with Boff's notion of a re-enchantment of creation:

But for many, questions still remain. How holy is the creation? How is an awareness of the Spirit's presence within the material world distinguished from worshipping the earth as sacred? Has the power of sin and death infected the nature of creation itself? Or has it only distorted humans in their relationship to creation ? $^{25}$

For me, the question in assessing Boff's work is therefore one of how the "Catholic substance" and the "Protestant principle" can be integrated with one another (if at all).

b) Several theological perspectives in the $20^{\text {th }}$ century, most notably dialectical theology, emphasised God's transcendence and otherness. This served as a powerful critique against the ideologies of nationalism, racism, anti-Semitism and apartheid. By contrast, the new focus on the immanence of the Spirit encourages an appreciation of the intimate connections of God's Spirit with the created order. ${ }^{26}$ An emphasis on the immanence of

23. Boff (1988:194).

24. Boff is, of course, very sensitive to the many contemporary manifestations of sin and evil in the world (e.g. anthropocentrism, capitalism, religious legitimation of oppression, etc) (cf. also his discussion on original sin, 81-83). For Boff, sin implies the disruption of connections and connectedness (85). He is nevertheless confident in the ability of human consciousness to detect the divine presence in the world.

25. Granberg-Michaelson (1992:54).

26. Granberg-Michaelson (1992:54). 
God correlates with an emphasis on the sacredness of creation. Such a new appreciation for the sacred should deter the destruction of the environment.

However, a panentheist position does not necessarily guarantee a respect for the integrity of creation. Societies for whom nature was or still is sacred have nonetheless destroyed their natural habitation throughout the centuries. ${ }^{27}$ One may argue that panentheism attributes the dignity of creation not to its own worth, but as a consequence of it being an extension of the divine, or of the divine being present in it. ${ }^{28}$ The strength of classic theism is its ability to acknowledge the distinctness of creation in relation with God. Although this may lead toward a deist separation of the world from God, this distinction is crucial to protect the (ecological) integrity of the created order ${ }^{29}$ The earth is not simply an extension of God. Together with the rest of the cosmos, the earth comes forth from the being of God but thereafter remains distinct from God. To use an analogy: A baby coming forth from the mother's womb has to grow up and become a mature human person in her own right. The daughter cannot remain an extension of the mother forever. The mother has to allow the daughter the freedom to become distinct from her. The relative independence of the daughter from the mother is a condition for a relationship of mutual love and respect that will emerge between mother and daughter. This does not diminish the nourishing, nurturing, protecting love of the mother for the child in any way. Moreover, the mother will always remain "present" in the daughter genetically, through the mother's upbringing and through their lifelong companionship. Likewise, God's loving care for creation does not imply that creation has to remain merely an extension of Godself.

c) In Christian orthodoxy, the work of the Holy Spirit has always been closely related to that of Christ. Indeed, the Spirit is the Spirit of Christ. In recent ecumenical discussions on the filioque, participants from both the East and the West affirmed the intimate relationship between Jesus Christ and the Holy Spirit without subordinating the Spirit to the Son. This recognition has moved the filioque controversy towards one of understanding the complex and varied relationships between Father, Son and Spirit. In a technical sense, "procession" is only one way amongst many others that may be used to characterise these relationships. ${ }^{30}$

The rhetoric of Boff's brief discussion of the filioque is clearly to undermine what he labels the Christomonism of Latin theology, that is, the authoritarian tendency to encapsulate the freedom that characterises the work of the Spirit under the central figure of Christ (and, one may add, of ecclesial authorities). This, Boff suggests, has reinforced an "amnesia regarding the Holy Spirit" (166). One may argue that, for Boff, the person and work of Christ is one particular manifestation of the wide-ranging, indeed cosmic work of God's Spirit. This gives a certain priority to the Spirit, albeit that

27. Haught (1993:110-111).

28. See Field (1996:142).

29. Cf also Gunton (1993:161). Against the fashion of various theologies of immanence, Gunton argues that theologies of transcendence allow for human independence and freedom by leaving space between the divine and the human (1993:36). The distinction between God and the world allows for a system of coordinates that helps us to comprehend the world and our place within the world. Gunton explains:

The term 'coordinates' is the crucial one here, for it implies a system in which particulars are truly related to one another, and yet in such a way that 'space' remains between them. We need coordinates if we are to know who we are and what our world is - a perspective from which to view and assess our various interests and actions. If there is no space between God and the world; or rather, no God to give things space in which to be, we lose the space between one another and between ourselves and the world of particulars without which we are not truly what we are (1993:71).

30. See Oberdorfer (2001). 
the person and work of Christ is regarded (in terms of Teilhard's schema) as a perfection of the divine presence.

This does raise some further questions though. In Teilhard's schema, the emergence of human consciousness constitutes the transition from biogenesis to noogenesis. Likewise Christogenesis, is understood as the emergence of a new form of (Christic) consciousness that permeates the cosmos. In both cases, it is a particular form of consciousness, based on increasing levels of complexity, that yields liberating possibilities. This begs the question as to whether cosmic pneumatology can offer an adequate soteriology. ${ }^{31}$ Furthermore, is salvation merely a different form of knowledge, a new form of consciousness? Does this not constitute a noetic reduction of Christian soteriology? And is this sufficient to bring liberation for the oppressed, ecological healing for destroyed environments and victory over the many contemporary forms of evil?

In my view, Christian theology should retain its soteriological focus. It has to reflect on the concrete and vivid narratives of God's salvific involvement in the history of the cosmos in general and in the history of humanity in particular. This requires that Rahner's famous rule should be adhered to: the theological emphasis should be on the economic trinity in order to avoid rampant speculation about perichoretic relationships within the immanent trinity. ${ }^{32}$ At the same time, Christian soteriology has to be rooted within a far more thorough reintegration of the doctrines of creation, redemption and consummation. The value of Teilhard's schema is that it does manage to integrate cosmological insight with a Christocentric vision. The question is whether the costs of this integration are not too high for an adequate Christian soteriology.

31. Van de Beek (1987:218).

32. It should be noted that Boff does acknowledge the close correlation between the immanent trinity and the economic trinity, also with reference to Rahner's rule. See Boff (1988:214). 


\section{BIBLIOGRAPHY}

Boff, L \& Elizondo, V (eds) 1995. Ecology and poverty. Cry of the earth, cry of the poor. Concilium 1995/5. London: SCM Press.

Boff, L 1988. Trinity and society. Tunbridge Wells: Burns \& Oates.

Boff, L 1994. Social ecology: Poverty and misery. In: Hallman, DG (ed) 1994. Ecotheology. Voices from South and North, 235-247. Geneva: World Council of Churches.

Boff, L 1995. Ecology and liberation. Maryknoll: Orbis Books.

Boff, L 1995. Liberation theology and ecology: alternative, confrontation or complementarity? In: Boff, L \& Elizondo, V (eds) 1995. Ecology and poverty. Cry of the earth, cry of the poor. Concilium 1995/5, 67-77. London: SCM Press.

Boff, L 1997. Cry of the Earth, cry of the poor. Maryknoll: Orbis Books.

Conradie, EM 1999. Stewards or sojourners in the household of God? Scriptura 73, 153-174.

Field, DN 1996. Reformed theology, modernity and the environmental crisis. Dissertation. University of Cape Town.

Gebara, Y 1995. Cosmic theology: ecofeminism and panentheism. In: MacKinnon, MH \& McIntyre, M (eds) 1995. Readings in ecology and feminist theology. Kansas City, Mo: Sheed \& Ward.

Gebara, Y 1996. The trinity and human experience. An ecofeminist approach. In: Ruether, RR (ed) 1996. Women healing earth. Third world women on ecology, feminism and religion, 13-23. Maryknoll: Orbis Books.

Gebara, Y 1999. Longing for running water: Ecofeminism and liberation. Minneapolis: Fortress Press.

Granberg-Michaelson, W 1992. Redeeming the creation: The Rio Earth summit: Challenges for the churches. Geneva: World Council of Churches.

Gunton, C 1993. The One, the Three and the Many: God, creation and the culture of modernity. Cambridge: Cambridge University Press.

Haught, JF 1993. The promise of nature: Ecology and cosmic purpose. Mahwah, NJ: Paulist Press.

Hessel, DT (ed) 1996. Theology for earth community: A field guide. Maryknoll: Orbis Books.

Jantzen, G 1984. God's world, God's body. Philadelphia: The Westminster Press.

Klingenthal Memorandum 1979. The filioque clause in ecumenical perspective. In: Link, HG (ed) 1985. Apostolic Faith Today: A handbook for study. Faith and Order Paper 124. Geneva: World Council of Churches.

McFague, S 1990. Imaging a theology of nature: the world as God's body. In: Birch, BC, Eakin, W \& McDaniel, JB (eds) 1990. Liberating life: contemporary approaches to ecological theology, 201-227. Maryknoll: Orbis Books.

McFague, S 1993. The body of God. An ecological theology. Philadelphia: Fortress Press.

Moltmann, J 1981. The Trinity and the kingdom. San Francisco: Harper \& Row.

Moltmann, J 1985. God in creation: An ecological doctrine of creation. London: SCM Press.

Moltmann, J 1989. Creating a just future: the politics of peace and the ethics of creation in a threatened world. London: SCM Press. 
Müller-Fahrenholz, G 1995. God's Spirit transforming a world in crisis. New York: Continuum.

Oberdorfer, B 2001. The filioque problem - History and contemporary relevance. Paper read at a meeting of the Theological Society in the Western Cape, 2 March 2001.

Rae, E 1994. Women, the earth, the divine. Maryknoll: Orbis Books.

Ruether, RR 2000. Conclusion: Eco-justice at the center of the church's mission. In: Hessel, DT \& Ruether, RR (eds) 2000. Christianity and ecology. Seeking the wellbeing of earth and humans, 603-614. Cambridge: Harvard University Press.

Sindima, H 1989. Community of life. Ecumenical Review 41:4, 537-551.

Van de Beek, A 1987. De adem van God: De Heilige Geest in kerk en kosmos. Nijkerk: GF Callenbach.

Welker, M 1994. God the Spirit. Philadelphia: Fortress Press. 